\title{
Production and economic viability of banana managed with cover crops
}

\author{
Francisca E. L. Barbosa ${ }^{1}$, Claudivan F. de Lacerda ${ }^{2}$, Aiala V. Amorim ${ }^{3}$, \\ Raimundo N. T. Costa ${ }^{2}$, José A. da Silva ${ }^{2} \&$ Fernando F. F. Hernandez ${ }^{4}$ \\ ${ }^{1}$ Instituto Federal de Educação, Ciência e Tecnologia Cearense/Campus Ubajara/Eixo de Produção Alimentícia. Ubajara, CE. E-mail: edineidelb@gmail.com \\ ${ }^{2}$ Universidade Federal do Ceará/Centro de Ciências Agrárias/Departamento de Engenharia Agrícola. Fortaleza, CE. E-mail: cfeitosa@ufc.br (Corresponding \\ author); rntcosta@ufc.br; adrianoagronomia@yahoo.com.br \\ ${ }^{3}$ Universidade da Integração Internacional da Lusofonia Afro-Brasileira/Campus da Liberdade/Instituto de Desenvolvimento Rural. Redenção, CE. E-mail: \\ aialaamorim@unilab.edu.br \\ ${ }^{4}$ Universidade Federal do Ceará/Centro de Ciências Agrárias/Departamento de Ciência do Solo. Fortaleza, CE. E-mail: ferrey@ufc.br
}

\section{Key words:}

perennial legumes

Musa spp.

nitrogen

\begin{abstract}
A B S T R A C T
This research aimed to evaluate the yield and economic viability of three crop cycles of the banana cv. 'Prata Anã in association with perennial herbaceous legumes, natural vegetation, or compared with the conventional management. The research was conducted using a complete randomized block design with split-split plots and four replicates. The plots were formed by four irrigation depths: 50, 75, 100 and 125\% of crop evapotranspiration, and the subplots by cover crops (Calopogonium muconoides, Pueraria phaseoloides, and natural cover without $\mathrm{N}$ addition) or no cover crops with addition of $\mathrm{N}$ fertilization (conventional management). The subsubplots were formed by the second, third and fourth banana production cycles. Yield and economic viability of the cultivation were estimated for a period of seven years. The conventional management promoted greater yield and economic viability in the cultivation of 'Prata Anã banana, due to the $\mathrm{N}$ fertilization. Managements with leguminous cover crops were also economically viable, but they should be investigated in combination with $\mathrm{N}$ fertilization and compared with the conventional method.
\end{abstract}

\section{Palavras-chave:}

leguminosas perenes

Musa spp.

nitrogênio

\section{Produtividade e viabilidade econômica da bananeira associada com plantas de cobertura}

\section{R E S U M O}

Objetivou-se, com este trabalho, avaliar a produtividade e a viabilidade econômica em três ciclos da bananeira cv. Prata Anã em associação com leguminosas herbáceas perenes, vegetação nativa ou comparadas com o manejo convencional. A pesquisa foi conduzida utilizando-se delineamento em blocos casualizados com parcelas subsubdivididas com quatro repetições. As parcelas foram formadas por quatro lâminas de irrigação: 50, 75, 100 e $125 \%$ da evapotranspiração da cultura e as subparcelas por plantas de cobertura (Calopogonium mucunoides, Pueraria phaseoloides e vegetação espontânea sem adição de N) ou tratamento com adubação nitrogenada sem plantas de cobertura (manejo convencional). As subsubparcelas foram representadas pelos segundo, terceiro e quarto ciclos de produção da bananeira. Foram estimadas a produtividade e a viabilidade econômica do cultivo para um período de sete anos. O manejo convencional proporcionou maior produtividade e viabilidade econômica no cultivo da bananeira Prata Anã em função da adubação nitrogenada. Manejos com plantas de cobertura leguminosas também foram viáveis economicamente mas devem ser investigados em combinação com a adubação nitrogenada e comparada com o método convencional. 


\section{INTRODUCTION}

Banana is the second fruit most produced in the world and the third most produced in South American countries, such as Brazil, which was the fifth largest producer of this fruit in 2012 (FAO, 2015). In spite of that, the global mean yield of the crop is $14.5 \mathrm{Mg} \mathrm{ha}^{-1}$, which is considered as low (FAO, 2015). In Northeast Brazil, the highest yields were equal to 14 $\mathrm{Mg} \mathrm{ha}^{-1}$, recorded in the state of Bahia. On the other hand, in the 2014/2015 season, the state of São Paulo recorded yield of 21.05 $\mathrm{Mg} \mathrm{ha}^{-1}$ (IEA, 2015).

There are many factors contributing to the low yields, such as: disuse of adequate techniques in soil tillage, low quality of seedlings and soil fertility, low rainfalls and cash flow (Chopin \& Blazy, 2013). In this context, a possible, although less sustainable, way of increasing banana yield is the intensification in the use of mineral fertilizers in the crop management. However, intensive agriculture has caused negative impacts (Tscharntke et al., 2012).

A sustainable alternative would be the association of banana crop with leguminous cover crops. From the agricultural, environmental and economic points of view, this management is interesting because it increases the $\mathrm{N}$ supply to the subsequent crop cycles (Doneda et al., 2012), provides biomass, favoring soil fertilization and its structuration, contributes to the conservation of the water in the soil (Barbosa et al., 2013), besides reducing the costs with the application of herbicides (Dorn et al., 2013).

In the semiarid region of Ceará, studies with the use of leguminous cover crops in association with banana trees have been successfully performed (Barbosa et al., 2013; Pereira et al., 2016), which is of great importance for family farming, widely developed in semi-arid regions and fundamental for the national banana production. However, aspects related to the economic viability of these systems, comparing them with the conventional management, have not yet been studied.

Considering the above mentioned factors, this study aimed to evaluate the yield and economic viability in three cycles of banana, cv. 'Prata Anã', in association with perennial herbaceous leguminous crops, in the management of live mulching.

\section{Material AND Methods}

This research comprehended the second, third and fourth cycles of the banana cv. 'Prata Anã, conducted from May 2011 to April 2014, at the Vale do Curu Experimental Farm (FEVC), which belongs to the Federal University of Ceará (UFC), in the municipality of Pentecoste, CE, Brazil (3 $48^{\prime} \mathrm{S} ; 3^{\circ} 1^{\prime}$ $\mathrm{W} ; 47 \mathrm{~m}$ ). According to Köppen's classification, the climate is BSw'h' (hot and semi-arid, with rainy season possibly delayed to autumn). The mean annual rainfall is $797 \mathrm{~mm}$ and the potential evapotranspiration is $1847 \mathrm{~mm}$, with critical period of water deficit from June to January.

The soil of the experimental area is classified as Fluvic Neosol and has the following chemical characteristics: $\mathrm{pH}$ (water) $=7.1 ; \mathrm{EC}=0.36 \mathrm{dS} \mathrm{m}{ }^{-1} ; 0.75 \mathrm{~g} \mathrm{~kg}^{-1}$ of N; $24 \mathrm{mg} \mathrm{kg}^{-1}$ of P; $13.3 \mathrm{~g} \mathrm{~kg}^{-1}$ of OM; CEC of $12.95 \mathrm{cmol}_{\mathrm{c}} \mathrm{kg}^{-1} ; 92 \%$ of V; and
9.1, 2.2, 0.27, 0.99, 0.05 and $0.38 \mathrm{cmol}_{\mathrm{c}} \mathrm{kg}^{-1}$ of $\mathrm{Ca}^{2+}, \mathrm{Mg}^{2+}, \mathrm{K}^{+}$, $\mathrm{H}^{+}+\mathrm{Al}^{3+}, \mathrm{Al}^{3+}$ and $\mathrm{Na}^{+}$, respectively.

The experimental design was randomized blocks with split-split plots and four replicates. The primary treatment (plots) was formed by four irrigation depths: 50, 75, 100 and $125 \%$ of crop evapotranspiration (ETc). The subplots consisted of management treatments: conventional (with $\mathrm{N}$ fertilization and absence of cover crops) and with cover crops: calopo (Calopogonium mucunoides Desv.), tropical kudzu (Pueraria phaseoloides Benth.) and spontaneous vegetation. The subsubplots consisted of the second, third and fourth production cycles of the banana crop.

Each plot $(12 \times 40 \mathrm{~m})$ was composed of four rows of banana, cv. 'Prata Anã, planted in single-row system, at spacing of $3 \mathrm{x}$ $2 \mathrm{~m}$ and a total of 80 plants. The subplots had dimensions of $12 \times 10 \mathrm{~m}$, with twenty plants, and the six central plants were used for evaluation.

The leguminous crops calopo and tropical kudzu were planted one month after the banana crop and distributed in the interrows, in seven rows spaced by $0.25 \mathrm{~m}$, at a planting density of 30 seeds per linear meter for both species. The spontaneous vegetation was considered as all plants grown naturally in the interrow of the banana crop in the subplots selected for this treatment. The species Panicum maximum Jacq was predominant in the spontaneous vegetation. At approximately every three months, the leguminous crops were cut (mowing) at height of $0.15 \mathrm{~cm}$ from the soil.

The micropropagated banana seedlings were planted in early November 2010, in holes with dimensions of $0.40 \times 0.40$ $\mathrm{m}$. Basal fertilization consisted of $10 \mathrm{Mg} \mathrm{ha}^{-1}$ of bovine manure, $83 \mathrm{~kg} \mathrm{ha}^{-1}$ of dolomitic limestone and $25 \mathrm{~kg} \mathrm{ha}^{-1}$ of FTE BR 12 (micronutrients). Based on soil analysis and crop requirements, during the first cycle (Barbosa et al., 2013), plants received 315 $\mathrm{kg} \mathrm{ha}^{-1}$ of $\mathrm{N}$ in the conventional management and $32 \mathrm{~kg} \mathrm{ha}^{-1}$ in the other treatments. In the second, third and fourth cycles, macronutrients (NPK) were added twice a year, totaling 405 $\mathrm{kg} \mathrm{ha}^{-1}$ of $\mathrm{N}, 35 \mathrm{~kg} \mathrm{ha}^{-1}$ of $\mathrm{P}_{2} \mathrm{O}_{5}$ and $570 \mathrm{~kg} \mathrm{ha}^{-1}$ of $\mathrm{K}_{2} \mathrm{O}$, applied in the form of urea, single superphosphate and potassium chloride, respectively. $\mathrm{N}$ fertilizers were not applied in the subplots with cover crops.

The phytosanitary management of banana and cover crops occurred always when necessary, through the application of chemical insecticides and fungicides. The area was irrigated using a sprinkler system, with one emitter for two plants. Irrigation was managed based on reference evapotranspiration (ETo) and crop coefficients (Kc). The sum of rainfalls (obtained from the weather station located at the FEVC) during the three cycles corresponded to $1041.9 \mathrm{~mm} ; 436.6 \mathrm{~mm}$ in the second cycle, $324.1 \mathrm{~mm}$ in the third cycle and $281.2 \mathrm{~mm}$ in the fourth cycle.

The water depths applied via irrigation and summed to the rainfall corresponded to totals in the second cycle of 632, 984, 1264 and $1580 \mathrm{~mm}$ at the water depths of 50, 75, 100 and $125 \%$ ETc. In the third cycle, the totals were 1036, 1554, 2072 and $2590 \mathrm{~mm}$ for the water depths of 50, 75, 100 and 125\% ETc. Lastly, in the fourth cycle the total volumes of water through rainfall and irrigation depths of 50, 75, 100 and 125\% ETc were $830,1245,1660$ and $2075 \mathrm{~mm}$, respectively. 
During the period of harvest (maturation stage 1 or 2 ) of each cycle, bunches were harvested from the evaluated plants and the yield was calculated based on the data of fruit weight and planting density per hectare.

The economic viability was determined based on the following indicators: operational cost, gross revenue, net revenue, profitability index and investment analysis: benefit/ cost ratio (B/C), net present value (NPV), internal rate of return (IRR) and payback period (time necessary for the investment to be paid), considering the costs and investments for installation and conduction of the orchard and actual revenue $\left(1^{\text {st }}\right.$ to $4^{\text {th }}$ cycle), estimated until the $7^{\text {th }}$ year. It should be pointed out that the economic analysis considered the data of production costs and banana yield of the $1^{\text {st }}$ cycle, presented by Barbosa et al. (2013).

The interest rate used in the study was $2 \%$ an year, based on the table of the National Program to Support Family Farming - Pronaf. This program is intended for family farmers that exploit a piece of land in the condition of landowners, squatters, tenants or partners who have annual gross income above $\mathrm{R} \$$ $6,000.00$ and up to $R \$ 110,000.00$. The program also presents, in the conditions of pay back of the contract, grace period of up to three years.

In the present research, the selling price of the bananas used in the financial analysis was equal to $0.80 \mathrm{R} \mathrm{kg}^{-1}$ and the price of the $\mathrm{N}$ fertilization was equal to $1.52 \mathrm{R} \mathrm{ha}^{-1}$. The other values referring to the production costs that compose the previously mentioned analysis were obtained from a control of the production organized along the experiment. The cost of irrigation comprised the cost of the water plus the value of the electricity tariff.

The cost of the water consisted of the sum of the coefficients $\mathrm{K}_{2.1}$ (fixed cost, dependent on the number of hectares) and $\mathrm{K}_{2.2}$ (variable cost, dependent on the pumped volume of water), values charged by the Irrigation District that administers the Irrigated Perimeter and estimated from the data presented by Costa et al. (2011). The electricity tariff was calculated based on the equation of Frizzone (Monteiro et al., 2007), described below:

$$
\mathrm{CE}=0.7457 \times \mathrm{Pow} \times \mathrm{To} \times \mathrm{P}(\mathrm{kWh})
$$

where:

CE - cost of electricity during the crop cycle, R\$;

0.7457 - conversion factor from hp to $\mathrm{kW}$;

Pow - motor power, in hp;

To - time of operation of the system necessary to apply the irrigation depth, in $\mathrm{h}$, considering a 1-ha irrigated area; and,

$\mathrm{P}(\mathrm{kWh})$ - Price of the $\mathrm{kWh}$, in $\mathrm{R} \$$.

The obtained data were subjected to analysis of variance (Anova) and, when significant by $\mathrm{F}$ test, compared by Tukey test with $p<0.05$ and regression analysis. In the regression analysis, the equations that best fitted were selected based on the significance of the regression coefficients at 0.01 and 0.05 probability levels by $F$ test and on the highest value of determination coefficient $\left(R^{2}\right)$, using the statistical program Sisvar 5.0.

\section{Results AND Discussion}

Yield was higher in the $4^{\text {th }}$ cycle (Figure 1A), with mean of $19.8 \mathrm{Mg} \mathrm{ha}^{-1}$. This was the only cycle with significant fit of the regression, a linear increment in yield with the increase in irrigation depths. Except for the management with spontaneous vegetation, in the $3^{\text {rd }}$ cycle (Figure $1 \mathrm{~B}$ ) all the others showed yields higher than $14.5 \mathrm{Mg} \mathrm{ha}^{-1}$ (global mean) and the mean values in the three cycles were equal to $24.8,16.4,17.0$ and 15.8 $\mathrm{Mg} \mathrm{ha}^{-1}$ for the conventional management, calopo, tropical kudzu and spontaneous vegetation, respectively.

It has been evidenced that the banana yield increases each cycle until it reaches a maximum, from which it starts to decrease. This tendency was presented by Fernandes et al. (2008), who observed quadratic behavior in the production of 'Prata Anã banana, with maximum point in the sixth year of cultivation. Oliveira et al. (2008) also observed, among thirteen banana cultivars, including 'Prata Anãa, that the yield in the $3^{\text {rd }}$ cycle was higher than in the $2^{\text {nd }}$ cycle.

It is also known that the greater soil moisture favors the banana production, since it favors the absorption of nutrients. However, the relationships between the total volume of water applied and the production variables are not always linear. This fact is generally associated with the negative effect of the excess water (Damour et al., 2012), frequently reached at the highest water depths applied.

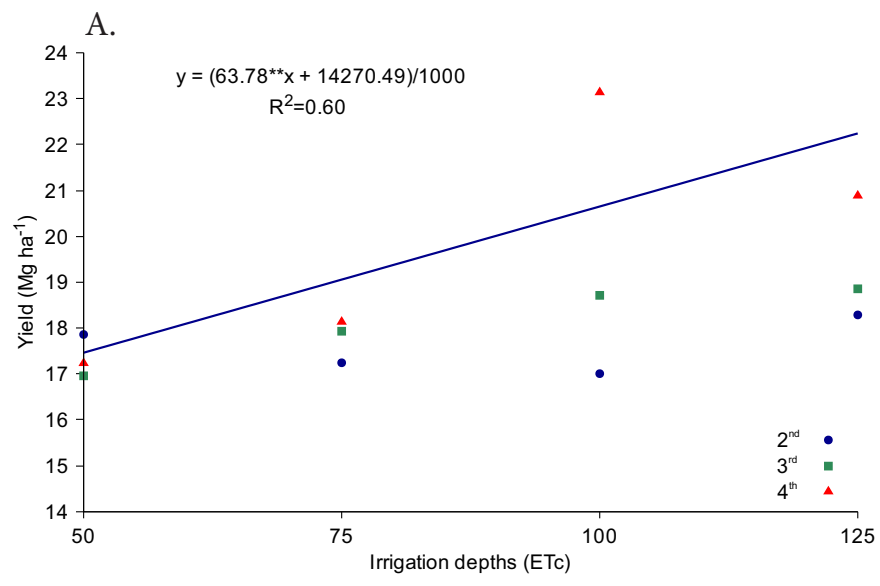

B.

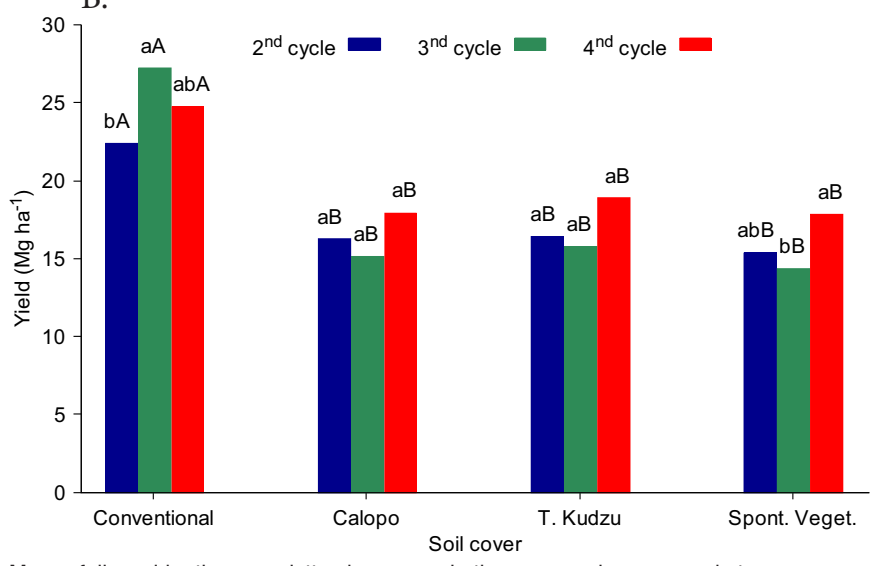

Means followed by the same letter, lowercase in the cover and uppercase between covers, do not differ by Tukey test at 0.05 probability level

Figure 1. Data of the interaction of irrigation depth $\mathrm{x}$ crop cycle (A) and soil cover $x$ crop cycle (B) for the yield of 'Prata Anã' banana 
The better performance of the conventional management (Figures 1A and B) is mainly attributed to the $\mathrm{N}$ fertilization. In addition, it is worth emphasizing the influence of residues of banana crop on the nutrition of the crop, since the banana residues left on the soil as mulch, after harvest, sometimes guarantee yields equal to those of other cover crops, due to the supply of $\mathrm{N}$ (Muliele et al., 2015). Absolute yield values in the conventional treatment are also consistent with studies that used similar amounts of N (Alves et al., 2010).

For cover crops, lower yields result from the lower $\mathrm{N}$ supply. However, it should be pointed out the importance of the longer time of continuous incorporation of residues in these treatments in order to increase soil $\mathrm{N}$ content and, consequently, increase the yield.

Regarding the parameters of the investment analysis (Table 1), economic viability occurred in all treatments and the conventional management reached the highest $\mathrm{B} / \mathrm{C}$ ratio, NPV and IRR, as well as the shortest payback period. The conventional management was followed by the management with leguminous crops, which showed on average NPV of R\$ $47,529.18$, IRR of $74 \%$ and payback period of 3.05 years. The treatment with spontaneous vegetation showed NPV of R\$ $38,405.64$, IRR of $60 \%$ and payback period of 3.73 years, and these values were lower in R $9,420.45$ for NPV, $14 \%$ for IRR and superior in 0.68 years for the payback period.

It should be pointed out that, although there were no significant differences in the yields of the $2^{\text {nd }}, 3^{\text {rd }}$ and $4^{\text {th }}$ cycles between the managements with cover crops, in the $1^{\text {st }}$ crop cycle (considering the viability analysis) the yield of the spontaneous vegetation was significantly lower (Barbosa et al., 2013), influencing the results of economic viability of the present study.

In monetary terms (determined by the NPV), the economic return of the conventional management in relation to that with tropical kudzu was on average (considering all irrigation depths) equal to $\mathrm{R} \$ 52,417.66$ or approximately $52 \%$. Converting this value to the current minimum wage, which is $\mathrm{R} \$ 788$, it can be claimed that, under the conditions of this study, one hectare of banana produced under conventional management generates approximately 128 minimum wages, in seven years. In the case of cover with tropical kudzu, one hectare would generate 61 minimum wages, in the same period.

Considering the conditions of the Pronaf and a period of seven years, the investment would be completely paid in about two years in the conventional management and three years in the other treatments. For the conventional treatment and those with cover crops, the lowest irrigation depth (50\% ETc) promoted the highest economic return.

Studies that deal with the economic analysis of the banana crop under similar conditions are scarce; thus, it is difficult to make comparisons. In spite of that, Furlaneto et al. (2007) observed economic viability in the production of banana, cv. 'Grande Naine', conducted under conventional management and the payback period was achieved in the $4^{\text {th }}$ year, a time longer than the 1.8 and 3.2 years observed in the conventional management and other managements of the present study, respectively (Table 1).

The superiority of the conventional management in terms of economic viability mostly resulted from the yield, approximately $23 \%$ higher in relation to the other managements with cover crops. In the treatments with leguminous crops, besides the lower yield, the total production costs were only about 4.9 and $4.3 \%$ lower than the production costs in the conventional management, for calopo and tropical kudzu, respectively.

The small difference in the production costs between the conventional management and the management with cover crops is mostly a result of the costs with phosphate and potassium fertilizations, maintained in the treatments with cover crops. It becomes clear when the fertilization costs are considered separately, with difference of only $38 \%$ in the values of fertilization in the conventional treatment, in comparison to the others. The costs with purchase of seed also influenced the production costs, especially among the leguminous crops that had different prices, such as tropical kudzu, whose price per hectare was 2.4 times higher than that of calopo seeds.

Considering only leguminous plants, the higher production cost of the management with tropical kudzu was determinant in the payback period and IRR (Table 1). In spite of that, the highest yield obtained in this treatment (in the first crop cycle, presented by Barbosa et al., 2013) guaranteed greater NPV (most important indicator from the financial analysis point of view). In the case of spontaneous vegetation, despite the lower costs (for not requiring the purchase of seeds), the lower yield made this treatment economically less viable.

As to the monetary differences referring to the economic viability of the managements with cover crops, in comparison to the conventional one, it should be highlighted that, despite

Table 1. Economic viability of the production of 'Prata Anã' banana cultivated under conventional management and management with cover crops, under different irrigation depths for the period of seven years and interest rate of $2 \%$

\begin{tabular}{|c|c|c|c|c|c|c|c|c|}
\hline \multirow{2}{*}{ Treatments } & \multicolumn{8}{|c|}{ Irrigation depths } \\
\hline & $B / C$ & NPV (R\$) & IRR (\%) & Payback & $B / C$ & NPV (R\$) & IRR (\%) & Payback \\
\hline & \multicolumn{4}{|c|}{ ETC $50 \%$} & \multicolumn{4}{|c|}{ ETC $75 \%$} \\
\hline Conventional & 2.14 & $100,561.27$ & 147.39 & 1.82 & 2.13 & $100,346.73$ & 146.78 & 1.83 \\
\hline Calopo & 1.57 & $47,549.79$ & 76.30 & 2.9 & 1.56 & $47,335.26$ & 75.86 & 2.91 \\
\hline Tropical Kudzu & 1.57 & $48,143.61$ & 72.73 & 3.16 & 1.57 & $47,929.07$ & 72.32 & 3.17 \\
\hline \multirow[t]{2}{*}{ Spontaneous vegetation } & 1.46 & $38,723.16$ & 60.42 & 3.7 & 1.46 & $38,508.63$ & 60.03 & 3.72 \\
\hline & \multicolumn{4}{|c|}{ ETc $100 \%$} & \multicolumn{4}{|c|}{ ETc $125 \%$} \\
\hline Conventional & 2.13 & $100,139.04$ & 146.20 & 1.84 & 2.12 & $99,927.93$ & 145.61 & 1.85 \\
\hline Calopo & 1.56 & $47,127.57$ & 75.43 & 2.92 & 1.56 & $46,916.46$ & 74.99 & 2.94 \\
\hline Tropical Kudzu & 1.57 & $47,721.39$ & 71.93 & 3.19 & 1.56 & $47,510.27$ & 71.53 & 3.21 \\
\hline Spontaneous vegetation & 1.46 & $38,300.94$ & 59.65 & 3.74 & 1.45 & $38,089.82$ & 59.27 & 3.77 \\
\hline
\end{tabular}

$\mathrm{B} / \mathrm{C}$ - benefit/cost ratio; NPV - Net present value; IRR - Internal rate of return 
their lower economic return, managements with leguminous crops can be viable, especially in the family farming system and in situations of lower availability of capital for investment. In addition, they bring benefits, for reducing the use of herbicides (Dorn et al., 2013) and incrementing soil organic matter.

Despite the lower number of minimum wages generated by the management with tropical kudzu, if it were conducted in the family farming system, which uses its own labor, 84 minimum wages would be added to the 61 (result of the conversion from NPV to minimum wages), referring to the payment of the labor considered in the production costs. In this case, the same hectare conducted under management with tropical kudzu, in seven years, would achieve a total of 145 minimum wages or $\mathrm{R} \$ 1,361.00 /$ month for 84 months ( 7 years), and this single value is higher than the income of most family farmers of regions such as Rio Grande do Sul (Schneider et al., 2006). In addition, these managements allow environmental advantages (Dorn et al., 2013).

\section{Conclusions}

1. The conventional management promoted higher yield and economic viability of 'Prata Anã banana, with yield above $27 \mathrm{Mg} \mathrm{ha}^{-1}$.

2. Managements with leguminous cover crops were economically viable, since they are also able to promote profits before the half of the years considered in the investment.

3. The irrigation depth of $50 \%$ ETc promoted the best economic returns, regardless of the management used.

\section{ACKNowledgments}

To the Federal University of Ceará (UFC) for the logistic support; to the Brazilian Northeast Bank (BNB), National Institute of Science and Technology in Salinity (INCTSal) and to the Coordination for the Improvement of Higher Education Personnel (Capes), for the financial support and the scholarship.

\section{Literature Cited}

Alves, M. da S.; Coelho, E. F.; Paz, V. P. da S.; Andrade Neto, T. M. de. Crescimento e produtividade da bananeira cv. Grande Naine sob diferentes combinações de nitrato de cálcio e uréia. Revista Ceres, v.57, p.125-131, 2010. http://dx.doi.org/10.1590/S0034737X2010000100020

Barbosa, F. E. L.; Lacerda, C. F. de; Feitosa, H. de. O.; Soares, I.; Andrade Filho, F. L. de; Amorim, A. V. Crescimento, nutrição e produção da bananeira associados a plantas de cobertura e lâminas de irrigação. Revista Brasileira de Engenharia Agrícola e Ambiental, v.17, p.1271-1277, 2013. http://dx.doi.org/10.1590/ S1415-43662013001200004

Chopin, P.; Blazy, J. M. Assessment of regional variability in crop yields with spatial autocorrelation: Banana farms and policy implications in Martinique. Agriculture Ecosystems \& Environment, v.181, p.12-21, 2013. http://dx.doi.org/10.1016/j.agee.2013.09.001
Costa, R. N. T.; Oliveira, V. K. R. de; Araújo, D. F. de. Planejamento, gerenciamento e uso racional de águas em perímetros públicos de irrigação. In: Medeiros, S. de S.; Gheyi, H. H.; Galvão, C.de O.; Paz, V. P. da S. (ed.). Recursos hídricos em regiões áridas e semiáridas. Campina Grande: Instituto Nacional do Semiárido, 2011.p.87-111.

Damour, G.; Ozier-Lafontaine, H.; Dorel, M. Simulation of the growth of banana (Musa spp.) cultivated on cover-crop with simplified indicators of soil water and $\mathrm{N}$ availability and integrated plant traits. Field Crops Research, v.130, p.99-108, 2012. http://dx.doi. org/10.1016/j.fcr.2012.02.013

Doneda, A.; Aita, C.; Giacomini, S. J.; Miola, E. C. C.; Giacomini, D. A.; Schirmann, J. Fitomassa e decomposição de resíduos de plantas de cobertura puras e consorciadas. Revista Brasileira de Ciências do Solo, v.36, p.1714-1723, 2012. http://dx.doi.org/10.1590/S010006832012000600005

Dorn, B.; Stadler, M.; Heijden, M. V. D.; Streit, B. Regulation of cover crops and weeds using a roll-chopper for herbicide reduction in no-tillage winter wheat. Soil \& Till Research v.134, p.121-132, 2013. https://doi.org/10.1016/j.still.2013.07.014

FAO - Food and Agriculture Organization of the United Nations. <http://faostat3.fao.org/browse/area/21/e>. 5 Jul. 2015.

Fernandes, L. A.; Ramos, S. J.; Valadares, S. V.; Lopes, P. S. N.; Faquin, V. Fertilidade do solo, nutrição mineral e produtividade da bananeira irrigada por dez anos. Pesquisa Agropecuária Brasileira, v.43, p.1575-1581, 2008. http://dx.doi.org/10.1590/ S0100-204X2008001100017

Furlaneto, F. de P. B.; Martins, A. N.; Camolesi, M. R.; Esperancini, M. S. T. Análise econômica de sistemas de produção de banana (Musa spp.), cv. Grande Naine, na região do Médio Paranapanema, estado de São Paulo. Científica, v.35, p.188-195, 2007.

IEA - Instituto de Economia Agrícola. 2015. <http://www.iea.sp.gov. br/out/verTexto.php?codTexto=13588>. 10 Mai. 2015.

Monteiro, R. O. C.; Costa, R. N. T.; Leão, M. C. S.; Aguiar, J. V. de. Aspectos econômicos da produção de melão submetido a diferentes lâminas de irrigação e doses de nitrogênio. Irriga, v.12, p.364-376, 2007.

Muliele, M. T.; Bielders, C. L.; Astenp, J. A. van. Short and mediumterm impact of manual tillage and no-tillage with mulching on banana roots and yields in banana-bean intercropping systems in the East African Highlands. Field Crop Research, v.171, p.1-10, 2015. http://dx.doi.org/10.1016/j.fcr.2014.10.015

Oliveira, T. K. de; Lessa, L. S.; Silva, S. de O.; Oliveira, J. P. de. Características agronômicas de genótipos de bananeira em três ciclos de produção em Rio Branco, AC. Pesquisa Agropecuária Brasileira, v.43, p.1003-1010, 2008. http://dx.doi.org/10.1590/ S0100-204X2008000800008

Pereira, N. S.; Soares, I.; Miranda, F. R. de. Decomposition and nutrient release of leguminous green manure species in the Jaguaribe-Apodi region, Ceará, Brazil, CE. Ciência Rural, v.46, p.970-975, 2016. http://dx.doi.org/10.1590/0103-8478cr20140468

Schneider, S.; Conterato, M. A.; Koppe, L. R.; Silva, C. C. A pluriatividade e as condições de vida dos agricultores familiares do Rio Grande do Sul. In: Schneider, S. (ed.) A diversidade da agricultura familiar. 2.ed. Porto Alegre: UFRGS; 2006. p.137-165. Tscharntke, T.; Clough, Y.; Wanger, T. C.; Jackson, L.; Motzke, I.; Perfecto, I.; Vandermeer, J.; Whitbread, A. Global food security, biodiversity conservation and the future of agricultural intensification. Biological Conservation, v.151, p.53-59, 2012. http://dx.doi.org/10.1016/j.biocon.2012.01.068 